\title{
The AfD: Finally a Successful Right-Wing Populist Eurosceptic Party for Germany?
}

\author{
Kai Arzheimer*
}

\begin{abstract}
Within less than two years of being founded by disgruntled members of the governing CDU, the newly-formed Alternative for Germany (AfD) party has already performed extraordinary well in the 2013 General election, the 2014 EP election, and a string of state elections. Highly unusually by German standards, it campaigned for an end to all efforts to save the Euro and argued for a re-configuration of Germany's foreign policy. This seems to chime with the recent surge in far right voting in Western Europe, and the AfD was subsequently described as right-wing populist and europhobe.

On the basis of the party's manifesto and of hundreds of statements the party has posted on the internet, this article demonstrates that the AfD does indeed occupy a position at the far-right of the German party system, but it is currently neither populist nor does it belong to the family of Radical Right parties. Moreover, its stance on European Integration is more nuanced than expected and should best be classified as soft eurosceptic.
\end{abstract}

Germany is unusual amongst West European countries because all relevant parties (with the possible exception of the Left party) are unwavering supporters of European integration. Moreover, while the Radical Right is now a permanent feature a of many European democracies, the electoral successes of Germany's Radical Right parties have been very modest and confined to the subnational level.

\footnotetext{
*This is the author's version of the work. Please consult the published version for citation purposes: Kai Arzheimer (2015). "The AfD: Finally a Successful Right-Wing Populist Eurosceptic Party for Germany?" In: West European Politics 38, in print 
However, in 2013, only months before the General Election, a new party was formed that campaigned for a dissolution of the Eurozone and a radical re-configuration of German foreign policy. This new "Alternative for Germany" (Alternative für Deutschland or AfD for short) came tantalisingly close to the electoral threshold of five per cent. Nine months on, the party polled seven per cent in the 2014 European parliamentary election and was eventually admitted to the European Conservatives and Reformists group (ECR), which further soured the relationship between German Chancellor Angela Merkel and British Prime Minister David Cameron. In three (eastern) state parliamentary elections held in August/September 2014, the AfD did even better, capturing between 9.7 (Saxony) and 12.2 (Brandenburg) per cent of the vote.

The AfD has been described as eurosceptic and right-wing populist ${ }^{1}$ by its political rivals and by the mainstream media. If this description was correct, it would signal a qualitative shift in the structure of party competition in Germany. Moreover, due to such a party's blackmail potential visa-vis the moderate right, this would constitute a massive shock to the German party system, with considerable implications for Germany's future position on European integration and for German immigration policies. It is, however not at all clear if and to what degree such a classification of the AfD is warranted, as those terms are used rather indiscriminately in mediated discourses (Bale, Kessel, and Taggart, 2011).

The aim of this article is therefore simply to assess the AfD based on categories derived from the rich comparative literature on the Radical Right and on euroscepticism. Since the AfD is a very young party with no parliamentary record, the primary source of evidence the party's 2014 European manifesto. Additional information is drawn from material on the party's website and Facebook presence.

The remainder of this article is organised as follows: The next section briefly reviews the concepts that will be used in the analyses. The third section provides some background information on euroscepticism and right-wing radicalism in Germany, and on the short career of the AfD. The fourth section presents an in-depth analysis of the AfD's manifesto and other texts produced by the party. The final section summarises the main findings and puts them into perspective.

\footnotetext{
${ }^{1}$ E.g. Stuttgarter Zeitung 18/09/2013, page 4; TAZ 02/07/2014, page 5.
} 


\section{Concepts}

\section{Radical right-wing populism}

In the early 1980s, a new group of right-wing parties emerged in Western Europe. These parties differed significantly and systematically from mainstream parties of the right and were therefore portrayed as a new party family in the scholarly literature. While there is little disagreement as to which parties belong to this new family, research on these parties and their voters has been plagued by the twin questions of what exactly sets these parties apart from the mainstream right, and what adjectives ("radical", "populist", "extreme", "anti-immigrant" ...) best capture these differences.

More recently, Mudde (2007) has proposed a new scheme for classifying right-wing parties outside the mainstream that has won international acclaim because it accommodates a wide range of parties while identifying important differences between them. According to Mudde (2007, p. 19), the lowest common denominator for the party family is "nativism", an ideology that combines nationalism and xenophobia. Nativism is a broad concept that subsumes racism, ethnocentrism, and anti-immigrant sentiment. Nativism holds that non-native elements (persons, ideas, or policies) present a threat to the nation state, which should be as homogeneous as possible.

However, traces of nativism may be found within the manifestos of mainstream parties. Following Mudde (2007, pp. 21-23), to qualify as a Radical Right, a party additionally needs to display authoritarian tendencies, i.e. an aggressive stance towards political enemies and a preference for a strictly ordered society, strong leadership, and severe punishments for offenders. With authoritarianism comes a political bent that is not necessarily anti-democratic per se but goes against the grain of some of the fundamental values and principles of liberal democracy (Mudde, 2007. pp. 25-26) such as tolerance, pluralism, and the protection of minorities and their rights.

Within the Radical Right, Mudde then identifies a subgroup of parties that is also populist in nature. By populism, Mudde (2007, p. 23) means not just a style of political communication but rather a "thin ideology" (see Stanley, 2008) that pits the "pure people" against a corrupt elite and puts majority rule above human rights and constitutional checks and balances. This Populist Radical Right is arguably the most electorally successful subtype within the larger party family. 
Finally, a small (and not necessarily populist) subgroup of the Radical Right is actually antidemocratic. Borrowing from the long-standing practice in Germany, Mudde labels these parties as "Extreme Right".

While Mudde's system of definitions may not have ended the debate about terminology in the field, it obviously provides a useful tool for assessing new parties, and more generally for discussing developments in Germany within a wider European context.

\section{Euroscepticism and ideology}

Euroscepticism broadly refers to a negative stance towards European integration. As a field of scientific inquiry, it only took off in the late 1990s (see Vasilopoulou, 2013) when the "Post-Maastricht Blues" (Eichenberg and Dalton, 2007) kicked in. Mudde (2012) distinguishes between two main strands in this literature: the "North Carolina school", which clusters around the Chapel Hill dataset, and the "Sussex school", which chiefly relies on case studies of party manifestos. Whereas the "North Carolina school" aims at quantifying degrees of euroscepticism, the Sussex group introduced a qualitative distinction between "hard" and "soft" euroscepticism. "Hard" euroscepticism refers to a principled rejection of European integration that is ultimately incompatible with EU membership. "Soft" euroscepticism is not opposed to integration as such, but rejects the current state of European politics as well as the trajectory towards an "ever closer union" (Szcerbiak and Taggart, 2008, pp. 7-8).

Mudde 2012, p. 194) notes that in the face of low salience of Europe and euroscepticism, it can be surprisingly difficult to determine whether a party is soft eurosceptic, hard eurosceptic, or not eurosceptic at all. However, in the case of the AfD, which emerged as an anti-Euro party and drew up their first full-length manifesto in the context of the 2014 European election, there is clearly no lack of salience. The hard/soft distinction is therefore a useful template for the analysis of the AfD's ideology.

But it is not entirely obvious how euroscepticism relates to broader ideologies. In most West European polities, parties position themselves within a two-dimensional (Kitschelt, 1995 Benoit and Laver, 2006) or perhaps even three-dimensional (Bakker, Jolly, and Polk, 2012) space. The 
everyday language of politics, however, still relies on the traditional left-right-dichotomy, and most West Europeans are quite happy to place themselves on a unidimensional left-right-scale (Lo, Proksch, and Gschwend, 2014). While the precise meaning of "left" and "right" may vary across time and space (Huber and Inglehart, 1995), left-right-placement usually reflects the perceived distance between voters and parties as well as value-based preferences (Knutsen, 1997). The focal value on the right-hand side of this spectrum is inequality (that can be the result of some "natural order", mandated by tradition and authority, or the product of some market mechanism). The most important value on the left-hand side is equality (see e.g. Bobbio, 1997), realised through state regulation and redistribution of resource that may or may not infringe on liberty and property rights.

Data reported in Ray's (1999) early seminal contribution suggest that eurosceptic parties were by and large located at both ends of the political spectrum during the 1990s. The analysis by Marks et al. (2006), which draws on more recent data, confirms precisely such a curvilinear pattern, at least for Western Europe. But even at the very (right) extreme of the political spectrum, euroscepticism is neither omnipresent nor universally "hard" (Vasilopoulou, 2013). Therefore, a new party such as the AfD must be very carefully evaluated before it can be classified as right-wing, populist, eurosceptic, or all of the above.

\section{Conditions for radical right success: Demand, context, and supply}

Support for Radical Right parties varies considerably across time and political systems. The burgeoning literature has identified three groups of factors that can help to make sense of this variation: "Demand-side" variables refer to individual features such us gender, formal education, class, and, most importantly, political disaffection and anti-immigration attitudes (Brug and Fennema, 2007) that make voters more or less susceptible to right-wing mobilisation. Their effect is moderated by contextual conditions, which include institutional factors (e.g. the electoral system or the degree of political centralisation), socio-economic conditions (e.g. the unemployment rate or the annual number of new asylum applications), and political variables such as the salience of the immigration issue for other parties and the media, or the willingness of the elites to co-operate with the Radical 
Right (Arzheimer, 2009).

Demand-side and contextual variables collectively form the external environment to which a Radical Right party has to adapt, at least in the short term $2^{2}$ A third group of variables, however, is more or less under the control of the party. Such "supply-side" factors include the party's policy proposals, candidates for office, and general public appearance ${ }^{3}$ Amongst these, past research has highlighted the availability of a "charismatic leader" as a precondition for Radical Right success, although this hypothesis is highly contested (Brug and Mughan, 2007).

More recently, David Art (2011) has developed a more nuanced account that stresses the importance of party activists in general. In a nutshell, Art argues that the trajectory of Radical Right parties hinges on the nascent party's ability to attract a sufficient number of the right type of activists, which in turn depends on historical legacies and the initial reaction of mainstream political actors to the new party (Art, 2011, p. 31). To have a chance of electoral success, a new party needs many "moderates", i.e. nationalists who credibly subscribe to the rules of liberal democracy and steer clear of biological racism and neo-nazism. Ideally, these moderates should also have high social-economic status (SES) and a degree of political experience outside the Radical Right (Art, 2011, p. 33). Conversely, the emerging party should try to curb the number of "opportunist" members without strong political convictions and to avoid attracting any "extremist" activists who are openly hostile to parliamentary democracy: The latter group is prone to infighting over (highly fragmented) political principles, unwilling to temper their political demands in order to appeal to more moderate voters, and provide an easy target for any attempts to ostracise the new party. Moreover, they are often unexperienced (Art, 2011, pp. 35-40).

Whilst this article is chiefly concerned with the question of whether the AfD can at all be classified as Radical Right, Art's theory of radical right mobilisation provides a useful template for the next section and puts the AfD's electoral appeal in perspective.

\footnotetext{
${ }^{2}$ Most parties will of course try to alter this environment to their advantage.

${ }^{3}$ In a broader sense, the party's organisational structures and deployment of campaign funds could also go under that rubric, although these obviously depend on recruitment and supply of external resources.
} 


\section{Euroscepticism and the radical right in Germany}

\section{The lack of successful eurosceptic and right-wing parties}

German MPs generally support European integration and even subscribe to a "deep core belief" of "the EU as a good thing" (Kropp, 2010, p. 140). Almost all parliamentary parties in Germany are staunch proponents of European political integration. On the right, both the FDP and the $\mathrm{CDU} / \mathrm{CSU}$ have supported and shaped European integration from its inception in the 1950s, although the small Bavarian CSU has been occasionally been more critical of the commission and some European policies than its sister party. On the left, the SPD and the Greens have taken a similar stance, both in opposition and in government (Wimmel and Edwards, 2011, pp. 295-296).

Only the Left party have voted consistently against the treaties of Maastricht, Nice, and Lisbon, because they reject the "neo-liberal" Single European Market, the monetary and budgetary policies mandated by the Stability and Growth Pact, and the "militaristic" Common Foreign and Security Policy. But even the Left party have declared themselves pro-European in principle at these occasions (Wimmel and Edwards, 2011, pp. 306-308), which makes them soft eurosceptics.

Otherwise, German euroscepticism has been confined to a number of unsuccessful single-issue fringe groups such as the Pro-Deutschmark party, and to the country's three Radical Right parties (Lees, 2008): the Republicans, the DVU, and the NPD. While all three had occasional successes in state elections and the Republicans even were represented in the 1989-1994 EP, their support proved fickle, and neither of them has ever won representation in the Bundestag. Compared to other West European countries, this weakness of the Radical Right appears anomalous and makes Germany a large negative outlier in a statistical model of radical right voting in Western Europe that controls for demand-side and contextual factors (Arzheimer, 2009).

Art's assessment of Radical Right mobilisation in Germany (Art, 2011, pp. 190-208), however, provides a plausible explanation for this lack of right-wing success. German elites have stigmatised National Socialism and criminalised the use its symbols very early on whilst offering nationalist a home in the mainstream centre-right. This strongly discouraged 'moderates' and 'opportunists' from joining the NPD, DVU, or the Republicans. These parties in turn have always had a fixation 
with the past (Ignazi, 1992; Kitschelt, 1995), which ruled them out as serious political players and made it easy to create and maintain a cordon sanitaire between them and the main parties.

Against this backdrop, the meteoric rise of the AfD and its ability to steer clear of any Nazi connotations is a very unusua $4^{4}$ and significant development. Arguably, this success was only possible because the party was formed by "moderates" with very high SES, considerable civic skills, and some political experience (detailed in the next seciont), and rests on the party's continuing ability to ward off "extremists", or at least activists that are perceived as too extreme in the German context. This makes the question of the AfD's classification all the more pertinent.

\section{The making of the "Alternative for Germany"}

The AfD began its political life in September 2012 when a group of disaffected CDU members including Konrad Adam (born 1942), Alexander Gauland (born 1941), and Bernd Lucke (born 1962) founded a political action group called "Wahlalternative 2013" (an electoral alternative for the 2013 General election). While none of them played a leading role in the CDU, all three had been party members for several decades and were reasonably prominent figures: Adam and Gauland are well-known conservative journalists, while Lucke is a professor of economics who has been instrumental in organising two petitions by academic economists against the various bailout packages.

However, the AfD should not be considered a splinter party from the CDU, because the founding members were recruited from a broader centre-right background: Other signatories included 28 university professors (almost all of them economists), entrepreneurs and managers, and a former state party chair of the FDP (the Liberal party). The Wahlalternative's short manifestc 5 demanded that Germany should not guarantee any foreign sovereign debt, that all members of the Eurozone should be free to re-introduce national currencies or to join new currency unions, and that any further transfer of German sovereignty should be subject to a referendum.

Initially, the Wahlalternative was organised as a pressure group that supported the "Federation

\footnotetext{
${ }^{4}$ The 'Law and Order Party' (PRO) of the early 2000s initially took a similar approach, but was not interested in euroscepticism and remained confined to the city-state of Hamburg.

${ }^{5}$ The original manifesto is archived at http://web.archive.org/web/20120923000310/http://www.wa2013.de/ index $\cdot$ php?id=208. 
of Independent Voters", a fledgling umbrella organisation for community-based, voter associations that are often dominated by the owners of small local business. In January 2013, both organisations jointly drew up a slate of candidates for the state election in Lower Saxony. However, the list polled just over one per cent of the vote, much less than the five per cent required for parliamentary representation. Subsequently, the two groups parted ways, and in February 2013 the Wahlalternative's leadership formally founded the AfD as a political party, with the stated intention to run in the upcoming federal election on September 22. Adam, Lucke, and Frauke Petry (born 1975), a chemist and entrepreneur from the eastern state of Saxony, were elected to jointly lead the party.

By July, the party had drawn up a short manifesto that focused on monetary and fiscal policies, had set up branches in all 16 Länder, and had attracted more than 10,000 members ${ }^{6}$ In the end, the AfD garnered 4.7 per cent of the vote, the best result for any party competing for the first time since 1953. While the AfD narrowly missed the electoral threshold, this result was widely seen as a remarkable achievement that gained them a foothold in the political system and gave them access to state funding.

Over the following six months, the party focused on broadening their programmatic profile and shedding the image of the single-issue party. During this time, it became clear that there was considerable potential for conflict within the party. In some state-level branches, the leadership resigned or was ousted over allegations of financial, political, or personal misconduct.7 More importantly, it became clear that various factions (conservatives, liberals, right-leaning Christian Democrats and perhaps even Christian fundamentalists) were warring for influence within the party. In January/February 2014, a party conference that was supposed to select the candidates for the European election had to be suspended for a week, because the delegates could not agree on a slate. In March, another party conference rejected a change to the statutes that would have

\footnotetext{
${ }^{6}$ Merkur Online, http://www.merkur-online.de/aktuelles/politik/alternative-deutschland-afd-zustrom- $\epsilon$ norm-ueber-10000-mi html $(03 / 07 / 2014)$.

'RP Online 01/12/2013, http://www.rp-online.de/politik/deutschland/joerg-burger-ist-neuer-afd-chef-in-nrw-aid-1. $3857120 \quad(03 / 07 / 2014)$, Spiegel Online 28/12/2013, http://www.spiegel.de/politik/deutschland/ afd-lucke-will-hessischen-landesvorsitzenden-abwaehlen-lassen-a-941072.html (03/07/2014), Zeit Online 14/06/2014, http://www.zeit.de/politik/deutschland/2014-06/afd-thueringen-ruecktritt (03/07/2014).
} 
made it possible for Lucke to become sole party leader 8 Lucke barely managed to take control of a debate on the party's position on homosexuality (started by himself) and struggled to enforce a party line that stops short of open populism and hard euroscepticisim.

The most visible split within the party concerned the question of its future membership in a political group in the European Parliament. While Lucke was adamant that the AfD should join the ECR, some of the party's rank-and-file and the party's youth organisation "Young Alternative" would rather have worked with the Europe of Freedom and Democracy (EFD) group. Things came to a head when the Young Alternative invited Nigel Farage to give a lecture in Cologne 9 Lucke intervened but could neither forestall the event, nor was he successful in reprimanding Marcus Pretzell, one of the organisers and also a member of the party's executive committee and a candidate for the EP election.

Electorally, none of this did the party any harm. In the polls, support for the AfD had been consistently in the range of six to eight per cent. In the actual election, they won 7.1 per cent of the vote, which entitled them to seven seats in the European Parliament - as many as the Left party and more than the CSU or the FDP have won. The list of elected candidates includes only two women and reflects the bourgeois background of the party leadership 10 On June 12 , the seven joined the ECR, making it the third-largest faction in the EP.

\footnotetext{
${ }^{8}$ Süddeutsche Online 23/03/2014, http://www.sueddeutsche.de/politik/europa-parteitag-afd-lehnt-sanktionen-gegen-russland $1919526(03 / 07 / 2014)$.

'Deutsche Welle Online 29/03/2014, http://www.dw.de/united-against-the-european-union/a-17530053 $(03 / 07 / 2014)$.

${ }^{10}$ Lucke himself, Hans-Olaf Henkel, the former president of the Umbrella Organisation of German Industry (BDI), who favours a minimal state and has likened the EU to the former Soviet Union(Handelsblatt 03/10/2011, http://www.handelsblatt.com/meinung/kolumnen/kurz-und-schmerzhaft/ henkel-trocken-use-eudssr/4681178.html (03/07/2014)), Bernd Kölmel, a public servant with the BadenWürttemberg State Court of Auditors, Beatrix von Storch, an insolvency lawyer and fringe Christian-conservative homphobe activist, Joachim Starbatty, a retired professor of economics who has repeatedly (though unsuccessfully) sued the government over the Euro, Ulrike Trebesius, a civil engineer, and the aforementioned Marcus Pretzell, a lawyer and property developer.
} 


\section{An analysis of the "Alternative"}

\section{A quantitative analysis of the AfD's 2013 European election manifesto}

Even for European elections, German parties tend to formulate detailed manifestos that cover a lot of policy domains. The AfD is no exception to that rule. The 2014 European election manifesto is the party's first full-length policy document and therefore very well suited for assessing the party's official policy positions. To provide context for its analysis, the manifestos of the main parties, the leftist Pirates, and the right-wing extremist NPD were analysed, too.

At 4,894 words, the AfD's manifesto is close to the median length of 5,852 words. A number of function words (articles, conjunctions, prepositions etc.) were removed from the files. Running headers or footers, tables of contents and adverts were also discarded, but preambles and prefaces by the party leaders were retained. Because German is an inflected language, the "Snowball" stemming algorithm was applied to prepare the texts for quantitative analysis. Stemming aims at reducing words to their roots by removing suffixes and affixes so that different inflected forms are grouped together as a single item. While stemming is less accurate than full lemmatisation (determining the dictionary form of inflected words), it can be carried out quickly and efficiently to reduce the complexity of a text, and the loss in precision does not matter much in practical applications (Grimmer and Stewart, 2013, p. 272).

Although a number of very common German words had been discarded in the first step, some stems such as "Europ" and "EU" appear very frequently in all manifestos and are thus not useful for discriminating between parties. Therefore, the one per cent most frequent stems were removed. Following Grimmer and Stewart (2013 p. 273), very rare stems that collectively make up one per cent of the total corpus as well as stems that were exclusively used by a single party (typically the party name) were also disregarded.

The remaining 4,430 stems give a very clear impression of the AfD's priorities. Amongst the 15 most frequent concepts in the AfD manifesto are "member states", "Eurozone", "ECB", and "institutions". None of these words is amongst the top priorities of any other party. However, the analysis also reveals some similarities. "Competition" features prominently in the AfD's manifesto, 


\begin{tabular}{|c|c|c|c|c|c|}
\hline \multirow{2}{*}{$\begin{array}{l}\text { Party } \\
\text { Left }\end{array}$} & \multicolumn{5}{|c|}{ Five most frequent words/stems } \\
\hline & regional & work & combine & ecological & society \\
\hline Green & ecological & human rights & green & Euro & refugee \\
\hline Pirates & data & oppose & society & access & allow \\
\hline SPD & allow & work & education & citizens (female) & democratic \\
\hline CDU & co-operation & worldwide & digital & need & job \\
\hline FDP & opportunity & freedom & liberal & citizens (female) & responsible \\
\hline AFD & member state & demand & Euro & eurozone & reject \\
\hline $\mathrm{CSU}$ & Brussels & allow & future & freedom & needs \\
\hline NPD & (German) people & Brussels & today & foreign & domain \\
\hline
\end{tabular}

Table 1: The Five Most Frequent words/stems in Nine Election Manifestos

but also crops up frequently in the respective platforms of the FDP and the CDU. "Work" is a common concern of the Left party and the SPD, and both Christian Democratic parties frequently talk about "jobs". Even looking at just the top five words most frequently used by each party gives a good idea of what they stand for (see Table

The observation that the usage of certain words conveys information on ideological proximity and distance between parties has been formalised by Slapin and Proksch (2008), who derive a statistical model that links word frequency to an underlying left-right dimension. Slapin and Proksch also develop an estimation procedure they call "wordfish", which recovers ideological positions from political texts and ideological content of words while controlling for differences in the wordiness of political documents and the global distribution of words. Unlike the related "wordscore" method (Laver, Benoit, and Garry, 2003), "wordfish" does not require anchor texts and is thus ideally suited for uncovering the positions of new parties relative to a set of more familiar political actors.

For the present analysis, the words and nine parties were simultaneously scaled using version 1.3 of Slapin and Proksch's wordfish package for the R statistical system. The algorithm converged quickly on the point estimates. 95 per cent confidence intervals were generated by a parametric bootstrap procedure (a method that does not rely on a normal distribution of the estimates) using 500 draws (Slapin and Proksch, 2008, p. 710) ${ }^{11}$ Again, there were no convergence problems. The word ${ }^{12}$ most closely tied to left ideology are "Kürzungspolitik" (austerity policies), "erwerbslos" (unemployed), "Altersarmut" (pensioner poverty), "Migrantinnen" (an inclusive and neutral term

\footnotetext{
${ }^{11}$ The Graphs show the average of the boot-strapped point estimates. For the $b$ parameters that determine word "loadings" on the ideological dimension, these tend to differ somewhat from the maximum likelihood estimates, but for the $\omega$ parameters, the two sets are virtually identical.

${ }^{12}$ For the sake of readability, words are used here instead of the actual stems.
} 
for migrants), "Sozialcharta" (social charter), "EU-Politik" (EU politics), "Profit" (profit, a more derogatory term than "Gewinn"), "Rüstungsproduktion" (production of arms), "unbefristed" (openended, as in open-ended contract), and "nationalistisch" (nationalistic).

The most right-wing words are "fremd" (foreign or strange), "Volk" (the (German) people, in a very emphatic sense), "verhängnisvoll" (fatal or ominous), "einerseits" (on the one hand), "bürgerfern" (removed or insulated from the interests of ordinary citizens), "Asylbewerber" (asylum seekers), "Gender" (as in gender mainstreaming or similar bugbears of the right), "gängeln" (to boss around someone, typically used with reference to the behaviour of bureaucrats), "Bolognaprozess" (the implementation of the Bolgna accord in German Higher Education), and "schleichend" (creeping, typically referring to slow but sinister political change). As this vocabulary reflects both the socio-cultural and the economic dimension of the left-right dichotomy, the scaling displays a high degree of face validity.

Estimates for the party positions are very precise (Figure

Both the CSU and the AfD appear to the right of the FDP, slightly closer to the NPD than to the CDU. The confidence intervals for their positions overlap, which implies that they are statistically indistinguishable ${ }^{13}$ Lucke has repeatedly claimed that his party is neither left nor right 14 and even stated that the AfD represents a new breed of party ("Partei neuen Typs") at their founding conference ${ }^{15}$ - a very awkward pun on the Stalinisation of East Germany's Socialist Unity party in the 1940s. But their manifesto places them firmly at the far right of the political spectrum.

The position of the CSU is perhaps more surprising, because the Bavarian Christian Democrats have been a fixture of German politics since 1945. But the party has nonetheless been described as anti-immigration and (borderline) right-wing populist in the literature (Lubbers, Gijsberts, and Scheepers, 2002 Falkenhagen, 2013). Former leader Franz-Josef Strauß famously declared that "there must be no democratic party right of the CSU" (Raschke and Tils, 2013, 253, my emphasis).

\footnotetext{
${ }^{13}$ However, in the vast majority of the 500 bootstrap samples, the CSU is estimated to be slightly more right-wing than the AfD.

${ }^{14}$ E.g. Spiegel Online 22/03/2014, http://www.spiegel.de/politik/deutschland/ afd-parteitag-in-erfurt-bernd-lucke-attackiert-medien-a-960230.html (07/07/2014). 15.Zeit Online 18/03/2013, http://wWw.zeit.de/2013/17/alternative-fuer-deutschland-ausrichtung $(07 / 07 / 2014)$.
} 


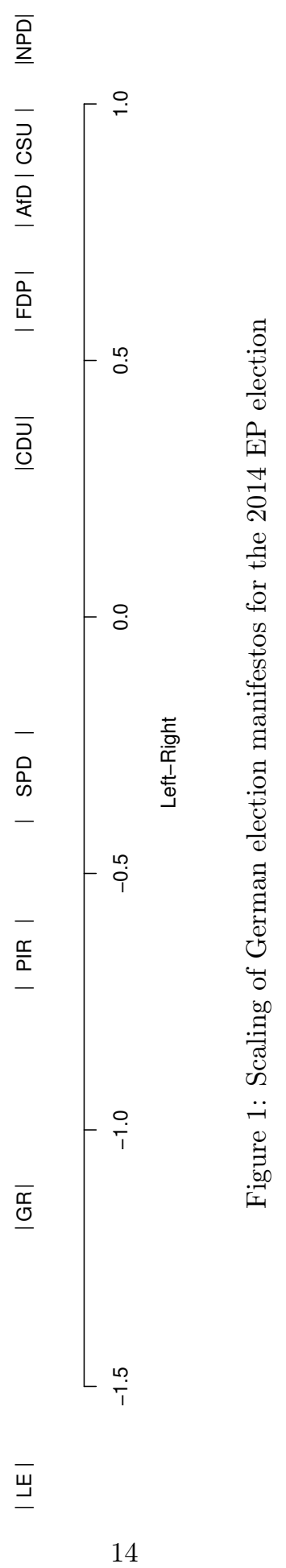


More recently, the party has also steered an ambiguous course towards the EU 16 While the content of their 2014 manifesto may already reflect concerns about the emerging competition from the AfD, the document is nonetheless in line with the CSU's traditional position at the very margin of the established party system.

\section{Is the 2013 manifesto radical, populist, and eurosceptic?}

Against this backdrop, the estimates for both the AfD and the CSU are highly plausible. The general left-right measure paints, however, a very broad-brushed picture of the AfD's political program. Assessing the question whether the AfD is not only on the right but also radical/extremist, populist, and eurosceptic requires a close reading of its manifesto.

In the theory section, "nativism", i.e. a mixture of nationalism and xenophobia was proposed as a criterion for separating the Radical Right from other right-wing parties. In line with their overall position on the right of the political spectrum, the AfD is certainly unusually prone (by German standards) to display national symbols and to emphasise Germany's national interest. "Mut zu Deutschland" (roughly translated: dare to stand by Germany) was the title of their manifesto and their main slogan for the EP 2014 campaign. The phrase is still used prominently on the party's main website, their social media profiles, and in other party material. The slogan alludes to the common right-wing argument that national pride is systematically discouraged in Germany but was deployed in a more specific sense during the campaign: the AfD wants Germany to act more assertively within the European Union 17

The corresponding section, however, is one of the shortest in the manifesto and makes rather modest demands. The AfD blames the member state governments for breaking the treaties (particularly the Stability and Growth Pact), it demands that the EP should launch a public inquiry into the details of bailout measures, and it suggests (without going into details) that Germany should

\footnotetext{
${ }^{16}$ With the tacit blessing of the leadership, a group of backbenchers have voted against the bailout legistlation and subsequently asked the Federal Constitutional Court to nullify these bills. The party's core political project in the 2013-2017 parliament is a special road charge for cars registered abroad that would probably violate of EU law, and the central plank of their 2014 campaign was the slogan "kick welfare cheats out", which referred to alleged "benefit tourists" from the eastern EU member states.

${ }^{17}$ This interpretation was emphasised by the design of the campaign posters, which surrounded the "EU" in "Deutschland" with the 12 European stars (shown in Figure
} 
have a greater say within the European institutions. However, the main opponent for the AfD is an unholy alliance between the EU institutions and Germany's "Altparteien" (old, i.e. established parties - a term the AfD has borrowed from the Green party of the 1980s). But one would be hard-pressed to find any statement that is nationalistic in the usual sense of the term in this or in fact in any other part of the manifesto.

The section on immigration and asylum also strikes a rather conciliatory tone. The AfD subscribes to the principles of free movement and free choice of residence for all EU citizens, although they want to limit benefits (of which they are critical in general) to long-term residents and their offspring. Moreover, the AfD acknowledges the problems brought about by demographic change and supports a point-based immigration regime for non-EU citizens. Finally, the AfD commits itself to a "humane" asylum system, which implies more financial and logistic support for the member states in the South, common standards for accommodation, and labour market access for asylum seekers. Taken together, these positions are not overly restrictive by German standards and do not display any nativist tendencies.

The AfD rejects Turkish EU membership flat-out and mentions "geographical, cultural and historical borders" in this context. But apart from this, and from a single reference to Europe's "Christian-occidental values", religion and culture, which are often used as politically acceptable codewords for non-European ethnic groups (Zúquete, 2008), are not at all mentioned in the text. Judging by its manifesto, the AfD is therefore not a Radical Right, let alone an Extreme Right party.

Is the AfD populist? If one defines populism as a "thin ideology", then there is very little in the manifesto that would support such a claim. The AfD is highly critical of "Brussels", and of the mainstream parties in Germany. They also argue that the ongoing financial crisis was to a large degree caused by irresponsible behaviour of the banks, which should be regulated more tightly. Moreover, they want to improve the democratic legitimacy of the EU in general and demand that future enlargements as well as important decisions on the Euro should be put to a referendum.

But that alone does hardly make them populists. Their manifesto does not contain a single reference to "elites", the "political class", or the "eurocrats". Corruption is mentioned only once, 
in the innocuous context of the UN's anti-corruption charter. But even if one opts for a broader, softer definition that primarily treats populism as a style of political communication "that refers to the people" (Jagers and Walgrave, 2007, p. 322) there is nothing in the manifesto that would appear as particularly populist in that sense.

The AfD's manifesto does not even conform with every day notions of populism that imply appeal to emotions, oversimplification, and a degree of opportunism (Mudde, 2004, pp. 542-543). On the contrary: The AfD's manifesto contains lengthy references to economic theory, is largely written in a rather technical and stilted language and even contains a couple of footnotes that cross-reference political demands to articles in the Treaty on the Functioning of the European Union.

That leaves the issue of euroscepticism. The AfD is clearly not a "hard" eurosceptic party. They are opposed to the currency union in its present form, to current and future bailouts, and more generally to a federal European state. But at the same time, they are committed to the European Union as such and have dropped their erstwhile demand for a return to the Deutschmark from their manifesto. While they want to strengthen the principle of subsidiarity (which was established in the Treaty of Maastricht at the behest of the German Länder), they don't intend to reduce the EU to a trade bloc. Although they are highly suspicious of secretive intergovernmental co-operation in Justice and Home Affairs, they support the pursuit of a Common Foreign and Security Policy based on lowest common denominator solutions. Taken together, "soft euroscepticism" best describes the political positions articulated in the manifesto.

\section{The Alternative's internet presence}

In Germany, parties are legally obliged to draw up comprehensive manifestos and lodge them with the Federal Returning Officer. These platforms are routinely scrutinised by researchers and the media. The lack of any obviously radical and populist content in the AfD's manifesto could therefore be misleading. Indeed, a speech delivered by Konrad Adam on June 27, 2012 18 gives a rather different impression. Adam encourages party members to become "dangerous citziens"

\footnotetext{
18 http://www .alternativefuer.de/konrad-adam-wie-wird-man-zu-einem-gefaehrlichen-buerger/.
} 
("gefährliche Bürger") who dare to take on the elites. Politicians of other parties are portrayed as greedy, lazy, and incompetent predators who are after the money of ordinary taxpayers and sell out the national interest to the EU, and the mainstream media help them to cover up.

Other speeches documented on the website, however (four by Lucke, one by Starbatty and one by Henkel) strike a similar, yet clearly more moderate tone. Starbatty and Henkel in particular discuss intricacies of social and economic policy in great detail, while Lucke often focuses on his vision for the further development of the party. None of these speeches could be considered populist or radical 19

To get a more rounded impression of the party's appeal, it therefore makes sense to analyse the party's presence on the internet. The party's main website (http://www.alternativefuer.de) is built with the wordpress platform. It is professionally designed and maintained and currently (July 2014) consists of more than 1,300 unique HTML pages ${ }^{20}$ plus 62 PDF documents. Many pages contain redundant content because they serve as archives that bring together posts related to a specific author, tag, category, or date of publication. Other pages are simply of an administrative nature (e.g. contact information). The following analysis is therefore restricted to 371 blog-post like pages, which contain comments on media reports, current events, or simply document statements by prominent party leaders.

For the analysis, only text in the main body of the pages was extracted. Stopword removal and stemming were conducted as outlined above. The resulting corpus consists of 45,990 words, which can be reduced to 9,745 stems. Obviously, posts on a website serve a function that is different from that of the manifesto, and this is reflected in the language used. A simple count demonstrates that the AfD is chiefly talking about itself and its leadership. "AfD" (573), "Alternative" (338), and "Deutschland" ("Germany", 531) are amongst the five most popular stems. Also very prominent is the name of Bernd Lucke (274), who clearly overshadows his fellow leaders Adam (42) and Petry (48). Far more important than Adam and Petry are deputy leaders Gauland (151) and Henkel

\footnotetext{
${ }^{19}$ More generally, Lucke and his party are the object of very intense scrutiny by their political adversaries and the mainstream media, yet there are very few verifiable public statements by Lucke or other members of the national leadership that could qualify as right-wing populist (see the borderline examples in Hler and Roeser, 2014. p. 37).

${ }^{20}$ This number excludes automatically generated overview pages for authors, tags, categories, and year of publication.
} 
(90), while (female) deputy leader Patricia Casale is not mentioned at all 21

Taken together, the website leaves no doubt that the AfD is a right-wing party. Only about 60 per cent of the references to "Germany" are due to the use of the full party name. The party simply talks a lot about Germany, everything German (253), Europe (379), the Euro (327), the EU (175), and the Eurozone (62). The tone is slightly harsher than that of the manifesto, with the occasional attack on the ECJ or refugees "who abuse the right to hospitality". While "Volk" (people) is rare, the more intellectual "Bevölkerung" (population, 42) and particularly "Bürger" (citizen(s), 169) crop up much more often. Attacks on the AfD's political competitors are also frequent: the CSU is mentioned 41 times, the FDP receives 75 references, and the CDU is mentioned 104 times.

But all in all, there is still little evidence of populism or right-wing radicalism. Immigrants and immigration are mentioned only 23 times (equivalent to a single mention in six per cent of all posts), and not necessarily in a negative context. Bulgaria and Romania are each referenced less than 15 times, Muslims hardly play a role at all, and even Turkey and the Turks are mentioned only 23 times. Remarkably, the AfD shows an unusual degree of sympathy for Russia and distrust for the US, both common in German Radical Right circles. But as far as foreigners are concerned, the main focus is clearly Greece and the Greeks (297 references).

The main website does not, however, include any interactive elements (guest books, comments, fora). Instead, the party relies on social media websites to interact with members, supporters, the media, and the general public. Facebook is of particular importance for the party. As of July 2014, the official fanpage of the AfD's federal organisation counts almost 122,000 "likes" 22 This is nearly twice as much as the SPD (just under 75,000 ) or the CDU (almost 84,000 ) can muster. On Twitter, the AfD federal organisation's handle has only about 9,600 "followers". The analysis will therefore focus on the AfD's Facebook fanpage.

\footnotetext{
${ }^{21}$ Another relatively prominent male is Starbatty (20), now a MEP. On the other hand, there are only five references to female MEP von Storch, and the second female MEP Trebesius is mentioned just once. The image of the party leadership that the website projects is reflected in the coverage by the German media: For the period from February 12013 to July 11 2014, LexisNexis lists 2096 news items mentioning both the AfD and Lucke and 622 items that refer to Henkel and the AfD. Adam, however is mentioned only 232 times, Gauland 231 times and Petry 185 times. von Storch is referenced 169 times, Starbatty 150 times, Trebesius 20 times, Pretzell four times, while there is just one article that mentions Casale.

${ }^{22}$ All 16 state level chapters as well as various regional and local chapters have set up their own fanpages, but those have much smaller fanbases, ranging from several thousands to less than a hundred.
} 
From a party's point of view, fanpages are attractive because they provide a focus for political conversation about the party that is actually under the control of the party. Whereas communication on Twitter is largely unmoderated, spontaneous, and ephemeral, Facebook fanpages resemble traditional home pages. Crucially, fanpage administrators can remove posts, restrict who may post, and even ban individual users from the page.

Facebook has created an application programming interface (API) that makes it easy to programmatically access posts on fanpages as well as their meta data. Data were collected using version 0.4 of the "Rfacebook" package for R. The AfD launched its fanpage on March 3, 2013, and posted for the first time on March 7. As of July 11, 2014, the AfD have updated their status 1,702 times, or roughly 24 times per week, with markedly higher frequencies immediately after the launch of the party, during the federal campaign, during the candidate selection conference in January/February, and finally during the European parliamentary campaign 23 Many of these updates include images that combine text and pictures. Figure 2 is quite a typical specimen that brings together a photo of Gauland, a short quote ("Germany is not the USA's doormat"), and the party logo and signature blue background. It is well known that such photo updates create quicker and stronger reactions with Facebook users and are privileged by Facebook's selection algorithm. Moreover, text within images is never truncated by Facebook and can be easily shared both on Facebook and across other channels with minimal effort.

The use of such imagery shows the professionalism of the AfD's social media team but is an obstacle for text analysis, because the use of various fonts and designs renders reliable optical character recognition virtually impossible. Fortunately, most images are complemented by some text, which usually re-iterates the main points or raises some additional issues. The following analysis is based on 1,223 posts that contain at least some text. Together, these posts make up some 72,000 words 24

Facebook is a popular medium for political communication because links to other content on the internet can be quickly posted (often with a preview of the other site's content), distributed, and

\footnotetext{
${ }^{23}$ This number could be inflated, as the Facebook API returns about 264 posts which do neither contain messages nor links, and which created no reactions. Presumably, these are either drafts or were retracted.

${ }^{24}$ This number includes URLs and symbols such as the hashtag sign.
} 


\title{
Alternative
}

für

Deutsehland

\section{ALEXANDER GAULAND:}

\author{
"Deutschland ist nicht \\ der Fußabtreter der USA!"
}

\section{MUT ZU DE ${ }_{\star \star \star}^{\star \star} \bigcup^{\star} T S C H L A N D$}

Figure 2: Montage of soundbite/logo 
commented upon. Until July, the AfD had posted 1,622 unique URLs which point to 187 separate domains. From these figures, it is clear that the AfD does not simply use Facebook to re-publish the content of its main website. Indeed, there are only 69 links (less than five per cent) to the party's national website, and 70 links to the websites of 19 local or regional party organisations.

The vast majority (795) of links refer to other content on Facebook. The party also makes extensive use of video clips hosted on youtube.com (79). Amongst the other sites, welt.de (the rightmost mainstream broadsheet) and faz.net (a centre-right broadsheet) are particularly prominent with 109 and 60 links, respectively. Other important mainstream sources include the business news sites handelsblatt.com (68) and wiwo.de (29) as well as news magazines focus.de (92, centre-right) and spiegel.de (58, centre-left). Finally, there is a host of links to various blogs and other websites.

In summary, the AfD use their Facebook page to direct attention to news articles that support the party's positions, to "spin" stories on issues that will chime with their supporters, and occasionally to poke fun at their political adversaries. But what exactly are they talking about in the text that accompanies links, videos, and images? Amongst the most frequent words in the posts are once more "AfD" (1,182), "Germany" (701), "Euro" (488) "alternative" (466), "EU" (400), and "Lucke" (367). Again, other party leaders are mentioned far less often. Greece (together with Greeks and "Athens") feature prominently once more with 202 mentions and are far more important than Turkey/Turks (48), Muslims/Islam (20), or Romania (9) and Bulgaria (8).

Apart from that, it is slightly easier to find populist rhetoric on the Facebook page than on the main website. While "elites" (which by any reasonable definition would include many AfD leaders) are hardly ever mentioned, there are ample references to a conflict between "politicians" and "citizens" as well as many calls for protecting "freedom" and "democracy". But even the most overtly populist post, the party anthem "We don't give up" is relatively tame: Germans are a "really super people" ("ein wirklich tolles Volk") who nonetheless "suffer", Chancellor Merkel is accused of treating "us" like a bunch of "right-less monkeys" while politicians more generally are guilty of writing incomprehensible and self-serving laws. The only solution to this crisis is to vote for the AfD.

Collectively, the AfD's posts were "shared" (copied to users' profiles or other pages) more than 
500,000 times. They received more than 1.9 million "likes" (on average, more than 1,100 per post) and over 325,000 comments, which amounts to over 200 comments per post.

Bloggers and mainstream journalists have repeatedly suggested that the AfD buys phantom fans and fake likes on Facebook. Comments, however, are much more difficult to simulate than shares and likes, and even a cursory glance at the AfD's page shows a remarkable level of real political interaction between users.

Somewhat surprisingly, not just "fans" but any Facebook user may comment and even post new content on the AfD's page. As of July 11 2014, almost 79,000 user-generated posts are accessible on the page. This is roughly equivalent to a corpus of 3.4 million words. Together, the posts have attracted more than 212,000 comments and just over 51,000 shares.

While members and supporters dominate, some critical voices exist amongst those who post on the AfD's page. At 7,980, the number of original posters is relatively low, and the distribution of posts across users is heavily skewed to the right (18.7). The median number of posts per user is just one. A minority of five per cent has posted 30 times or more, and a tiny group of 25 users (less than 0.5 per cent) is collectively responsible for a quarter of all posts ${ }^{25}$ While some of these 25 show off their sympathy for the AfD in their profile pictures and three hold party offices at the local level, none of them plays any significant role within the party or holds public office.

In terms of content, the 79,000 user-generated posts resemble the material posted by the AfD themselves. Again, "AfD" (26,311), "Germany" (12,816), "Euro" (11,152), and EU $(9,295)$ are amongst the most frequent words, while "Bulgaria", "Romania", "Turkey", and Muslims/Islam are of lesser importance. However, quite a few posts strike a tone that is markedly different from the party's carefully crafted statements. Resentment and nationalism colour many posts. Complaints about ungrateful immigrants, privileged homosexuals, and greedy politicians are frequent. Links to obscure right-wing sites abound.

The AfD have created a space for their supporters where this kind of talk is tolerated. But only up to a point: Racist slurs and even common expletives are very rare. This does not prove, but suggests, continuous interventions by the party. In various comments, the AfD has made it clear

\footnotetext{
${ }^{25}$ The number could be even smaller, as three of the most prolific posters have very similar surnames: Otto Blank,
} Andrea Blanc, and Andrea Cnalb. 
that they are actively monitoring the page, and that they delete racist or otherwise illegal content including links to right-wing extremist websites. There is no way of knowing how many items have been posted and subsequently deleted, but the party is treading a narrow line. On the one hand, the AfD does not want to annoy their most vocal supporters on the internet, on the other, Lucke is very wary of allegations of populism and radicalism.

\section{Conclusion}

This article set out to answer the question whether the AfD is a right-wing, populist, and eurosceptic party. A careful quantitative and qualitative analysis of the $2014 \mathrm{EP}$ manifesto shows that the AfD is indeed located at the far-right end of Germany's political spectrum because of their nationalism, their resistance against state support for sexual diversity and gender mainstreaming, and their market liberalism. They do, however, not qualify as "radical": There is no evidence of nativism or populism in their manifesto, which sets them apart from most of the other new right parties in Europe. Moreover, their euroscepticisim is of the "soft" variety. This assessment is largely confirmed by an analysis of the AfD's communication on the web, although statements by their facebook fans hint at more radical currents amongst supporters and the party rank-and-file.

Important nuances not withstanding, their current programmatic appeal most closely resembles that of the CSU. But while the CSU is essentially an "ethno-regional" (Falkenhagen, 2013) party that does not stand candidates outside Bavaria, the AfD aims at attracting a much bigger and broader national constituency.

Continued electoral support for the AfD would have profound repercussions for the existing German party system, most obviously by undermining the position of the CDU, which so far have fared much better than other Christian Democratic parties in Western Europe (Bale and Krouwel, 2013). In the longer run, it would directly or indirectly affect domestic, immigration, and European integration policies. Thus far, Chancellor Merkel has ruled out coalitions with the AfD. If the FDP's decline proves permanent and the AfD prevails, maintaining this cordon sanitaire will weaken the position of the CDU by forcing it to exclusively enter coalitions with the parties of the 
Left. At the same time, the AfD's success is already fuelling internal backlash from conservatives against Merkel's socially liberal policies.

Irrespective of the AfD's perspectives for long-term survival, the fact that the party has done so well in five consecutive elections reflects the scope of partisan dealignment in Germany and the increasingly fluid nature of its party system. But does this remarkable mobilisation guarantee a bright future for the AfD? Not necessarily. In absolute terms, the AfD's support has essentially stagnated, although the timing of the elections was close to optimal: In 2013, the AfD won 2.06 million votes, in the 2014 election it was 2.07 millions. In the eastern state elections, the AfD even suffered a small net loss of some 18,000 votes compared to their state-level results in the European election. Euroscepticism, the party's current core issue, is still not very salient in Germany. In a survey immediately before the EP election, only 47 per cent of the AfD's own voters had a wholly negative view of Germany's membership in the EU. Only 22 per cent rejected both Juncker and Schulz as president of the commission, and 40 per cent said they supported the AfD to register a protest vote, not because of their policies.

Precisely what these policies are might therefore change over the near future. So far, the "moderates" have dominated the party leadership. Lucke has been able to commit the AfD to civic nationalism, financial prudence, and soft euroscepticisim, with Gauland and Adam catering for a more broadly "liberal-conservative" right-wing audience that may feel left behind by Merkel's move to the centre. In 2014, Lucke's creation more closely resembles the British Conservatives than UKIP, let alone the French FN or the Austrian Freedom Party.

Yet Lucke's control over the party seems to be wavering. His plans to replace the joint leadership structure with a more traditional sole-leader role have been rejected by a party conference and have been met with criticism from his colleagues ${ }^{26}$ State and district party chapters are still struggling to keep right-wing extremists out. Meanwhile, their new status as MEPs has given other leading figures such as von Storch and Pretzell a platform. They represent less savoury brands of rightwing politics that could ultimately prove more attractive to voters than Lucke's polite exercises in

\footnotetext{
${ }^{26}$ FAZ Online 20/10/2014, http://www.faz.net/aktuell/politik/machtkampf-in-der-afd-lucke-und-die-ruecktrittsdrohung-1322 html (07/11/2014), Spiegel Online 29/11/2014, http://www.spiegel.de/politik/deutschland/ afd-bernd-lucke-laut-alexander-gauland-ein-kontrollfreak-a-1003889.html (29/11/2014).
} 
economic theory. Just how long the party resists that temptation remains to be seen.

\section{References}

Art, David (2011). Inside the Radical Right. The Development of Anti-Immigrant Parties in Western Europe. Cambridge: Cambridge University Press.

Arzheimer, Kai (2009). "Contextual Factors and the Extreme Right Vote in Western Europe, 19802002". In: American Journal of Political Science 53.2, pp. 259-275. DOI: $10.1111 /$ j .1540$5907.2009 .00369 \cdot x$.

— (2015). "The AfD: Finally a Successful Right-Wing Populist Eurosceptic Party for Germany?" In: West European Politics 38, in print.

Bakker, Ryan, Seth Jolly, and Jonathan Polk (2012). "Complexity in the European party space: Exploring dimensionality with experts". In: European Union Politics 13.2, pp. 219-245. DOI: $10.1177 / 1465116512436995$.

Bale, Tim, Stijn van Kessel, and Paul Taggart (2011). "Thrown Around With Abandon? Popular Understandings of Populism as Conveyed by the Print Media. A UK Case Study". In: Acta Politica 46.2, pp. 111-131. DOI: 10.1057/ap.2011.3.

Bale, Tim and AndrKrouwel (2013). "Down but Not Out. A Comparison of Germany's CDU/CSU with Christian Democratic Parties in Austria, Belgium, Italy and the Netherlands". In: German Politics 22.1-2, pp. 16-45. DOI: 10.1080/09644008.2013.794452.

Benoit, Kenneth and Michael Laver (2006). Party Policy in Modern Democracies. London: Routledge.

Bobbio, Norberto (1997). Left and Right. The Significance of a Political Distinction. Chicago: University of Chicago Press.

Brug, Wouter van der and Meindert Fennema (2007). "Causes of Voting for the Radical Right". In: International Journal of Public Opinion Research 19, pp. 474-487. URL: 10.1093/ijpor/ edm031. 
Brug, Wouter van der and Anthony Mughan (2007). "Charisma, Leader Effects and Support for Right-Wing Populist Parties". In: Party Politics 13.1, pp. 29-51. DOI: 10.1177/1354068806071260.

Eichenberg, Richard C. and Russell J. Dalton (2007). "Post-Maastricht Blues: The Transformation of Citizen Support for European Integration, 1973-2004". In: Acta Politica 42.2-3, pp. 128-152. URL: http://dx.doi.org/10.1057/palgrave.ap.5500182.

Falkenhagen, Frédéric (2013). "The CSU as an Ethno-regional Party". In: German Politics 22.4, pp. 396-420. DOI: $10.1080 / 09644008.2013 .833190$

Grimmer, Justin and Brandon M. Stewart (2013). "Text as Data. The Promise and Pitfalls of Automatic Content Analysis Methods for Political Texts". In: Political Analysis 21.3, pp. 267297. DOI: $10.1093 / \mathrm{pan} / \mathrm{mps} 028$

Huber, John and Ronald Inglehart (1995). "Expert Interpretations of Party Space and Party Locations in 42 Societies". In: Party Politics 1, pp. 73-111.

Hler, Alexander and Rainer Roeser (2014). Rechtspopulismus in Europa und die rechtspopulistische Lcke in Deutschland. Erfurt: MOBIT e.V.

Ignazi, Piero (1992). "The Silent Counter-Revolution. Hypotheses on the Emergence of Extreme Right-Wing Parties in Europe". In: European Journal of Political Research 22, pp. 3-34.

Jagers, Jan and Stefaan Walgrave (2007). "Populism as political communication style: An empirical study of political parties discourse in Belgium". In: European Journal of Political Research 46, pp. 319-345.

Kitschelt, Herbert (1995). The Radical Right in Western Europe. A Comparative Analysis. Ann Arbor: The University of Michigan Press.

Knutsen, Oddbjørn (1997). "The Partisan and the Value-based Component of Left-Right Selfplacement: A Comparative Study". In: International Political Science Review 18.2, pp. 191225. DOI: $10.1177 / 019251297018002005$

Kropp, Sabine (2010). "German Parliamentary Party Groups in Europeanised Policymaking: Awakening from the Sleep? Institutions and Heuristics as MPs' Resources". In: German Politics 19.2, pp. 123-147. DOI: $10.1080 / 09644001003774198$. 
Laver, Michael, Kenneth Benoit, and John Garry (2003). "Extracting Policy Positions from Political Texts Using Words as Data". In: American Political Science Review 97.02, pp. 311331. DOI: 10.1017. S0003055403000698. URL: http://journals . cambridge.org/article_ S0003055403000698.

Lees, Charles (2008). "The Limits of Party-Based Euroscepticism in Germany". In: Opposing Europe? The Comparative Party Politics of Euroscepticism. Vol. 1: Comparative and Theoretical Perspectives. Ed. by Aleks Szcerbiak and Paul Taggart. Oxford: Oxford University Press, pp. $16-37$.

Lo, James, Sven-Oliver Proksch, and Thomas Gschwend (2014). "A Common Left-Right Scale for Voters and Parties in Europe". In: Political Analysis 22.2, pp. 205-223. DOI: 10.1093/pan/ mpt028.

Lubbers, Marcel, Mérove Gijsberts, and Peer Scheepers (2002). "Extreme Right-Wing Voting in Western Europe". In: European Journal of Political Research 41, pp. 345-378.

Marks, Gary et al. (2006). "Party Competition and European Integration in the East and West Different Structure, Same Causality". In: Comparative Political Studies 39.2, pp. 155-175. DOI: 10.1177/0010414005281932.

Mudde, Cas (2004). "The Populist Zeitgeist". In: Government and Opposition 39.3, pp. 541-563.

- (2007). Populist Radical Right Parties in Europe. Cambridge: Cambridge University Press.

- (2012). "The Comparative Study of Party-Based Euroscepticism. The Sussex Versus the North Carolina School". In: East European Politics 28.2, pp. 193-202.

Raschke, Joachim and Ralf Tils (2013). Politische Strategie. Eine Grundlegung. 2nd ed. Wiesbaden: VS Verlag fr Sozialwissenschaften.

Ray, Leonard (1999). "Measuring party orientations towards European integration: results from an expert survey". In: European Journal of Political Research 36.2, pp. 283-306. DoI: 10.1111/ 1475-6765.00471.

Slapin, Jonathan B. and Sven-Oliver Proksch (2008). "A Scaling Model for Estimating Time-Series Party Positions from Texts". In: American Journal of Political Science 52.3, pp. 705-722. 
Stanley, Ben (2008). "The Thin Ideology of Populism". In: Journal of Political Ideologies 13.1, pp. $95-110$.

Szcerbiak, Aleks and Paul Taggart, eds. (2008). Opposing Europe? The Comparative Party Politics of Euroscepticism. Vol. 1: Comparative and Theoretical Perspectives. Oxford: Oxford University Press.

Vasilopoulou, Sofia (2013). "Continuity and Change in the Study of Euroscepticism. Plus ça change?" In: Journal of Common Market Studies 51.1, pp. 153-168. DOI: 10.1111/j.1468$5965.2012 .02306 \cdot \mathrm{x}$

Wimmel, Andreas and Erica E. Edwards (2011). "The Return of 'Social Europe': Ideas and Positions of German Parties towards the Future of European Integration". In: German Politics 20.2, pp. 293-314. DOI: 10.1080/09644001003774206

Zúquete, José Pedro (2008). "The European Extreme-Right and Islam: New Directions?" In: Journal of Political Ideologies 13.3, pp. 321-344. DOI: 10.1080/13569310802377019. 